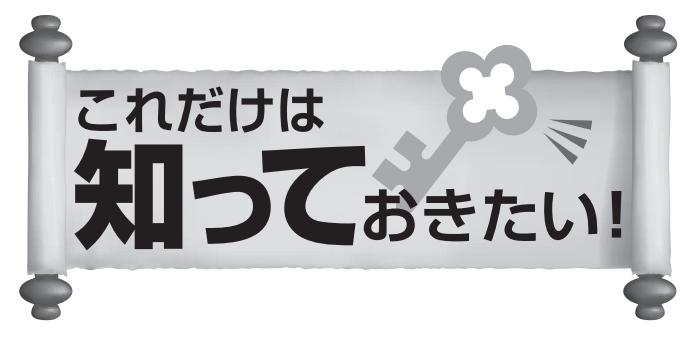

\title{
次世代シークエンサーが変える 不整眽の遺伝子診断
}

滋賀医科大学アジア疫学研究センター

大野聖子

\section{I 、はじめに}

次世代シークエンサー (Next Generation Sequencer : NGS)が登場してはや 10年が経過し，すでに次 世代，とはいえない時代になってきた。ささて，次世代というからには現世代があるわけで，現世代の シークエンスといえば Sanger法を主体としたダイレクトシークエンス(キャピラリーシークエンス)法 である，ヒトの全ゲノムを解読するというヒトゲノムプロジェクトは，このダイレクトシークエンス法 で行われたのだが，実に 13 年の時間と 2,700 億円もの費用を必要とした，その全ゲノム解読が， 20 年も 経過しないうちに10万円を切る時代やってきた(https : //www.genome.gov/sequencingcostsdata/). この費用の変化を知るだけで，いかに次世代シークエンサー技術が遺伝子診断を変えてきたかが予想で きるだろう。

\section{II. 従来法のシークエンス}

さて，NGSと従来型のシークエンサー，いわゆるダイレクトシークエンスとの大きな違いは何であ ろうか. それは 1 回の解析で得られる遺伝子情報量の違いである.

病気の原因となる遺伝子変異は, 主にアミノ酸に翻訳される領域, exonに存在する。 そのため, exonの外側の領域にある intronにプライマーを設定して PCRで増幅し, さらにダイレクトシークエン ス用の PCR (Sanger法)を行う(図 1上段)。こうして調整されたサンプルをキャピラリーシークエン サーで泳動する.ダイレクトシークエンスで解析できる塩基長は $800 \mathrm{bp}$ 程度に限定されるため, 一回 の解析では exon1個, intronの短い領域であっても 2 exon 程度に限定される. 先天性 QT 延長症候群 1 型(LQT1)の原因遺伝子, KCNQ1は 16 exonで構成されており, LQT1の遺伝子検查を行うためには, 1 検体につき 16 回の解析が必要である.

\section{NGSのしくみ}

NGSを使った遺伝子解析は，その標的とする領域の違いから主に3つに分類されている．ヒトの全ゲ ノムを読む全ゲノムシークエンス(Whole genome sequence：WGS), 全エクソン(exon)を読む全エク ソンシークエンス (Whole exome sequence : WES), 調べたい遺伝子・領域のみを選択したターゲット シークエンス(パネルシークエンス)の 3 種類である. WGSの場合, すべての領域を probeで増幅させ, WESでは exon 領域のみを probeで増幅させる. パネルシークエンスでは対象領域の probe をデザイン して増幅させる，複数の対象領域を一度に増幅し，得られたサンプルをNGS本体で一度に泳動する。 


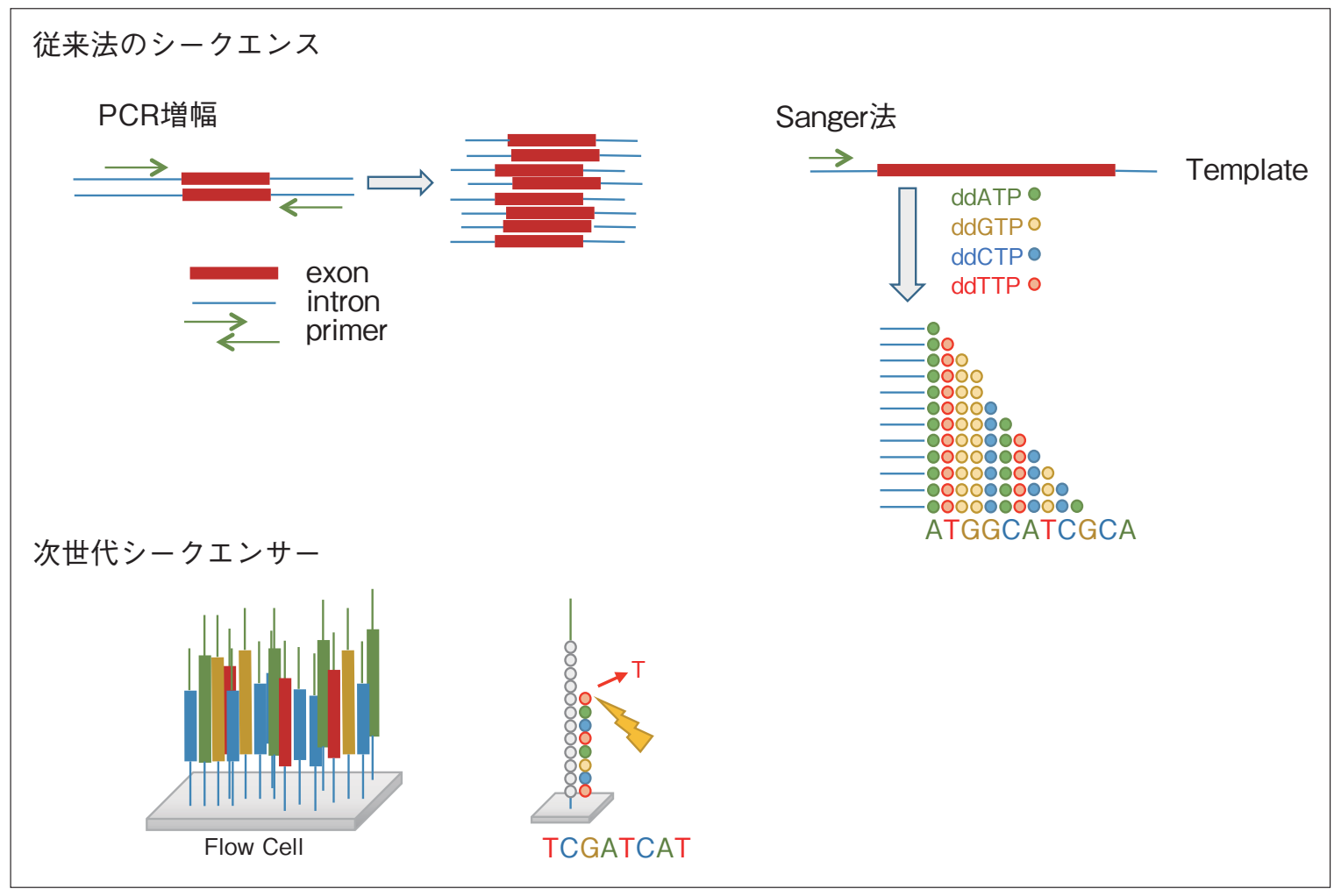

図 1 シークエンス解析法

上：従来法(Sanger 法). Intronに設定したPrimerを用いて exonを増幅させる(左). PCRで増幅した exon部分を 鋳型(template)として ddNTPを用いて伸長反応を行い，塩基配列を確定する(右).

下：次世代シークエンサー. Flow cell上に増幅産物を結合させる(左)。その増幅産物を鋳型として, 一塩基ずつ 増幅させ，一反応ごとにカメラで撮影を行い，塩基配列を決定する(右).

私が使用している illumina社のシステムの場合, 増幅させた個々のサンプルを Flow cell と呼ばれるガ ラス板上に結合させ，そのサンプルを鋳型として一塩基ずつ伸長させる反応を行う(図 1下段)。一塩基 を伸長させるごとにカメラで撮影を行い，どの塩基が増幅されたか記録していく．NGS本体での泳動 完了後, カメラで記録された塩基配列のデータが既存のヒトゲノムデータのどの部分に一致するのか, 確認して並べていく，そして既存のヒトゲノムデータと異なっている塩基配列を同定，つまり変異を同 定する．さらにインターネット経由での情報を活用することで，すでに報告されている変異かどうか， 健常人での同定頻度などの情報を付加することができる.

このように, 従来法のシークエンスが 1 exonごとに解析するのに対し, NGSでは一度の解析で対象 領域すべての塩基配列情報を知ることができる，さらにWeb上の情報を利用することで，変異に関す る様々な情報も同時に入手することができる。つまり，NGSは情報社会における遺伝子分野での発展 により，活用可能になったシステムであるといえる.

\section{N． 実際の遺伝子診断}

では，実際の遺伝子診断では何が可能になったのであろうか. LQTSの原因遺伝子はこれまでに 15 個報告されているが, 主要な原因遺伝子は $K C N Q 1, K C N H 2, S C N 5 A$ の 3 遺伝子であり, この 3 遺伝子 
に対して解析を行われることが多い. この 3 遺伝子の合計 exon数は 59 個であり, 従来法で LQTS患者 の遺伝子解析を行うためには, 最低でも59回に分けたサンプル調整およびシークエンサーでの泳動が 必要だった，一方，NGSではこの3つの遺伝子どころか，これまでにLQTSの原因として報告されて いる 15 遺伝子の全 exonを一度に解析することができる。ささらに, LQTSの類縁疾患であるカテコラミ ン誘発性多形性心室頻拍 (Catecholaminergic polymorphic ventricular tachycardia : CPVT)の主要な原 因遺伝子である $R Y R 2$ を解析することが可能になった。この $R Y R 2$ は exonが 105 個もある巨大な遺伝 子であり，これまではCPVTが疑われる場合でも，実際に遺伝子診断を行うことは困難であった，そ れがNGSでは, LQTSと CPVTの鑑別が困難な症例についても, 両疾患に対する遺伝子解析を同時に 行うことが可能になった.

では，これまで原因遺伝子が明らかにされていなかった疾患についてはどうであろうか. NGSを利 用したLQTSの新しい原因遺伝子が 2013 年に同定された ${ }^{1)}$. 血縁関係のない発端者 2 人は, 乳児期に QT延長から VFをきたした重症例であったが, どちらの発端者においても両親は健康で, 心電図上も QT延長を示していなかった，そこで，両親には変異がない新規突然変異が原因であると考えられ，各 家族につき両親と子供 (発端者)の 3 人に対してWESが行われた．新規突然変異でアミノ酸置換を伴い， これまでに報告のない変異を探したところ, カルモジュリンをコードするCALM1 と CALM2に変異が 同定された，その後，心停止をきたした二人の重症 LQTSについてもCALM1変異が同定され，CALM1 とCALM2 は LQTSの原因遺伝子であることが明らかにされた。このように新しい原因遺伝子を同定す るためにも，NGSは有用であることがわかる．

\section{NGSの弱点}

このように，非常に有用なNGSの解析であるが，NGSにも弱点がある。これまで遺伝子診断を行う 場合, 対象とする遺伝子のみを調べていた。そのため同定された変異は，ほぼ間違いなく疾患と関連し た遺伝子変異であった，ところが，NGSを用いて解析を行うと，原因と考えられる複数の遺伝子変異 が同定されることもある，複数の変異が同定された場合，実際にはどの変異が最も病気に影響している のか, それとも複数の変異が重複することによって病気を発症しているのか, 関連を調べて明らかにす る必要がある. また, 疾患の原因遺伝子であると報告されていても, 変異の報告数が少ない原因遺伝子 で, その遺伝子でコードされる物質の基礎的研究が少ない場合, 変異によって引き起こされる病気の説 明が困難なことも多い.さらに, NGSではシークエンサーから取り出した生のデータ (Raw data)から 質の悪い部分を除去し, 既存のシークエンスデータに合わせて得られたシークエンス配列を並べてい く，そのため, 間違ったデー夕を出力してしまう可能性, いわゆるノイズが出てしまう可能性がある. このノイズと実際の変異を見分けるために，変異が疑われる場合には，その部分のダイレクトシークエ ンスが必要になることも多い.

概念として説明すると, ダイレクトシークエンス法は目標とした魚を釣り上げる一本釣りのようなも のである. そのため, 一つの変異が見つかると，それを病気の原因である遺伝子変異と考える，一方， NGS は底引き網のようなもので, とりあえずたくさん変異を捕まえて, そこから必要である変異を選 んでいく，そのため，一度に多数の変異を同定することはできるが，本当に病気の原因である変異かど うか, 一つずつ確認する必要がある。また病気の原因と考えて選んだ変異が, 実は病気とはまったく関 係ない変異である可能性も残されている. 


\section{NGSの今後の展望}

これまで遺伝子診断は単一遺伝子疾患，いわ ゆるメンデルの法則に従う疾患で, 頻度の低い 遺伝子変異について主に行われてきた。図2左 上の遺伝性疾患で同定される非常に頻度の低い 変異については，その変異をもっていると必ず 疾患を発症すると考えられ，原因遺伝子変異の 疾患への影響が非常に強いことが考えられる.

一方, 頻度の高い変異 (多型)については, 生活 習慣病などの䍜患頻度の高い病気との関連がゲ ノムワイド関連解析 (Genome Wide Association Study : GWAS)で同定されてきている.ただ, GWASで関連付けられてきた多型は疾患に対 する影響が弱く，複数の多型が組み合わされる ことで, ようやく疾患リスクが上昇するような多型も多い.

NGSの登場により，ヒトの全ゲノム解析はますます容易になってきている，そうすると，これまで 遺伝性ではなく孤発性と考えられていた疾患 (図 2 中央) においても, 中等度の作用・頻度の遺伝子変異 の組み合わせで発症することが明らかにされていくと考えられる.

\section{VI. 最 後に}

NGSの登場で, 遺伝性疾患の遺伝子解析は劇的な進歩を遂げた. しかし, 患者の全ゲノム情報が得 られたとしても, それだけでは疾患の原因解明や治療法確立には不十分である。正確な臨床診断と, 遺 伝子変異に関連した基礎的な研究が組み合わされることで, 初めて医療の進歩に役立つことを, 改めて 肝に銘じたい。

\section{〔文献〕}

1) Crotti L, Johnson CN, Graf E, De Ferrari GM, Cuneo BF, Ovadia M, Papagiannis J, Feldkamp MD, Rathi SG, Kunic JD, Pedrazzini M, Wieland T, Lichtner P, Beckmann BM, Clark T, Shaffer C, Benson DW, Kääb S, Meitinger T, Strom TM, Chazin WJ, Schwartz PJ, George AL Jr : Calmodulin mutations associated with recurrent cardiac arrest in infants. Circulation, $2013 ; 127: 1009 \sim 1017$ 